\title{
EFEKTIFITAS PENGGUNAAN VIRGIN COCONUT OIL (VCO) TERHADAP PENCEGAHAN DIAPER RASH PADA BAYI USIA 1 - 12 BULAN DI WILAYAH KERJAPUSKESMAS DEPOK II SLEMAN
}

\author{
Jennifa ${ }^{1}$, Atik Ba'diah², Eni Purwaningsih ${ }^{3}$ \\ ${ }^{1,3}$ Prodi S1 IImu Keperawatan ${ }^{2}$ S1 Keperawatan POLTEKKES Kemenkes Yogyakarta
}

\begin{abstract}
Background : Diaper rash is a dermatitis eclusively localized in the diaper area, commonly attack children less than 2 years of age, usually conservatively cured by the parents so that only $7-35 \%$ babies suffer from diaper rash. Virgin Coconut Oil (VCO) that are beneficial to health, has been widely sought after to resolve health problems, also acts against bacteria and microbe. The Content of Medium Chain Triglycerides (MCT) in VCO hydrolyzed faster, and more quickly absorbed in the body tissue.

Aim :The aim of this research is to determine the effect of Virgin Coconut Oil on prevention diaper rash.

Methods : This research is pre-experimental with posttest only design. Conducted from May to June 2014. The research was done in Puskesmas Depok II Sleman area, with 14 respondents according to the determined criteria. Respondents were instructed to apply VCO in the diaper area once every morning after bath for 30 days. Data analysis used univariable analysis, bivariable analysis with Chi-Square test.

Result :The results of the data obtained in this study was $78.6 \%$ of respondents regularly use VCO, but not experiencing diaper rash and there are $21.4 \%$ of respondents do not regularly use VCO and $14.3 \%$ had diaper rash. The results showed there was significant effect of VCO on prevention diaper rash with a significance $p$ value $=0,003(p<0,05)$.

Conclution : Therefore it can be concluded that applying of VCO has a significant effective on prevention diaper rash. The use of VCO one time in the morning after a shower made for $\geq 21$ days was more effective against the prevention of diaper rash compared with the use of VCO $<21$ days.
\end{abstract}

Keywords : Virgin Coconut Oil (VCO), Diaper rash, Babies age 1 to 12 months. 


\section{PENDAHULUAN}

\section{A. Latar Belakang}

Diaper rash atau diaper dermatitis atau ruam popok adalah iritasi kulit yang meliputi area popok yaitu daerah lipatan paha, perut bawah, paha atas pantat, dan area genital (Manullang, 2010).Berdasarkan laporan Journal of Pediatrics Dermatology, penelitian di Inggris menemukan $25 \%$ dari 12.000 bayi berusia 4 minggu mengalami ruam popok (Shazia, et.al. 2007). Diaper rash juga mengenai $7-35 \%$ dari populasi bayi di Indonesia dan kurang lebih $50 \%$ bayi dan anak yang menggunakan popok pernah mengalaminya (Lucky, 2003).

Walaupun diaper rash bukan merupakan kelainan yang mematikan, namun bila dibiarkan akan semakin meluas sehingga bisa menggangu pertumbuhananak. Ketika anak sudah dewasa kelak, bukan tidak mungkin anak akan merasa malu karena bercak yang muncul sewaktu kecil akan membekas hingga dewasa. Sebagai upaya pencegahan agar diaper rash tidak terjadi, maka perawatan perianal atau perawatan pada daerah yang tertutup popok penting dilakukan (Darsana, 2009).

Virgin Coconut Oil (VCO) atau minyak kelapa murni mengandung $92 \%$ asam lemak jenuh yang sebagian besar merupakan Medium Chain Trygliceride (MCT) yang mempunyai kandungan anti mikroba dan anti bakteri.

Hal tersebut membuat peneliti tertarik untuk melakukan penelitian mengenai Efektifitas Penggunaan VCO Terhadap Pencegahan Diaper Rash pada Bayi Usia 1-12 bulan di Wilayah Kerja Puskesmas Depok II Sleman.

\section{B. Perumusan Masalah}

Berdasarkan latar belakang yang ada, maka masalah yang dapat dirumuskan dalam penelitian ini adalah "Bagaimanakah efektifitas penggunaan VCO terhadap pencegahan diaper rash pada bayi usia 1-12 bulan di Wilayah Kerja Puskesmas Depok II Sleman ?".
C. Tujuan

1. Tujuan Umum

Untuk mengetahui efektifitas penggunaan $V C O$ terhadap pencegahan diaper rash pada bayi usia 1-12 bulan di wilayah kerja Puskesmas Depok II Sleman.

2. Tujuan Khusus

Diketahuinya manfaat penggunaan VCO bagi kesehatan terutama bagi kesehatan anak dan diketahuinya frekuensi penggunaan VCO yang efektif dalam pencegahan diaper rash.

\section{Manfaat}

Hasil penelitian diharapkan dapat memberikan manfaat, sebagai berikut

1. Bagi Puskesmas Depok II Sleman.

Hasil penelitian ini diharapkan bermanfaat untuk mengembangkan promosi kesehatan kepada masyarakat tentang efektifitas penggunaaan VCO terhadap pencegahan diaper rash.

2. Bagi Keilmuan Keperawatan

Hasil penelitian dapat digunakan sebagai bukti dan acuan untuk meningkatkan keterampilan perawat dalam melakukan tindakan preventif terjadinya diaper rash pada bayi.

3. Bagi Masyarakat

Memberikan informasi berharga tentang penanganan klien yang mengalami diaper rash dan meningkatkan kerjasama antar keluarga dan tenaga kesehatan dalam upaya perawatan klien, baik di rumah maupun di pelayanan kesehatan.

4. Bagi Peneliti

Hasil penelitian ini diharapkan dapat menjadi dasar bagi penelitian berikutnya khususnya tentang pencegahan kejadian diaper rash. Memberikan pengalaman nyata dan menambah pengetahuan dalam melaksanakan penelitian.

\section{E. Ruang Lingkup}

Ruang lingkup penelitian adalah Wilayah Kerja Puskesmas Depok II Sleman setelah mendapat ijin untuk melakukan penelitian. 
METODE PENELITIAN

A. Jenis Penelitian

Jenis penelitian ini adalah penelitian

pra eksperimen (pre experimental design), dengan menggunakan rancangan "Posttest Only Design". Rancangan ini dilakukan dengan melakukan intervensi yaitu pengolesan VCO pada area perianal bayi, setelah itu dilakukan posttest (observasi tanda-tanda diaper rash). Penelitian ini tanpa kelompok kontrol.

B. Populasi dan sampel

Populasi dalam penelitian ini adalah bayi usia 1-12 bulan di Wilayah Kerja Puskesmas Depok II Sleman. Berdasarkan hasil studi pendahuluan yang telah dilakukan didapatkan data bahwa jumlah bayi yang berusia 1-12 bulan di wilayah penelitian adalah 15 bayi.

Dalam penelitian ini, responden yang dijadikan sampel penelitian memiliki kriteria inklusi dan eksklusi sebagai berikut:

Kriteria inklusi (kriteria yang diharapkan): Bayi berumur 1-12 bulan, menggunakan popok atau diaper disposable, dan orang tua bersedia bila anaknya menjadi responden penelitian.

Sedangkan kriteria ekslusi :Bayi yang menderita diaper rash, bayi yang menderita penyakit berat dan bayi yang lebih dari dua kali kunjungan tidak berada di rumah.

\section{Variabel Penelitian}

Variabel bebas dalam penelitian ini adalah pengunaan Virgin Coconut Oil. Sedangkan variabel terikat dalam penelitian ini adalah pencegahan diaper rash.

\section{Teknik Pengumpulan Data}

1. Dalam penelitian ini data primer diperoleh dari wawancara dengan orang tua responden, bidan di Puskesmas Depok II Sleman, serta kader posyandu.

2. Data sekunder dalam penelitian ini diperoleh dari Kartu Menuju Sehat (KMS) responden penelitian.

\section{E. Instrumen Penelitian}

1. Virgin Coconut Oil (VCO)

Penggunaan $V C O$ dengan cara mengoleskan sehari sekali setiap habis mandi di pagi hari dalam satu bulan di area perianal bayi.

2. Kalender Pengolesan VCO Kalender pengolesan $V C O$ berisi mengenai informasi apakah ibu sudah mengoleskan VCO kepada bayinya setiap hari, sehingga peneliti dapat menilai kepatuhan ibu dalam melakukan pengolesan VCO kepada bayinya.

3. Lembar Observasi

Lembar observasi adalah instrumen yang digunakan untuk menilai keefektifan penggunaan VCO terhadap pencegahan diaper rash, dengan

4. Standar Operasional Prosedur Pengolesan VCO

Adalah prosedur pengolesan VCO yang terdiri dari persiapan alat dan langkah-langkah pengolesan VCO pada area perianal bayi.

\section{F. Pengelolaan dan Analisa Data}

1. Analisis Univariat (Analisis Deskriptif)

Analisa hanya menghasilkan distribusi dan persentase dari tiap variabel. Tujuannya untuk menjelaskan atau mendeskripsikan karakteristik masing-masing variabel yang diteliti (Notoatmodjo, 2012).

2. Analisa Bivariat

Analisa bivariat dilakukan terhadap dua variabel yang diduga berhubungan atau berkorelasi (Notoatmodjo, 2012). Data yang diperoleh dilakukan analisa secara statistik dengan menggunakan Uji Chi Square.

\section{HASIL DAN PEMBAHASAN}

\section{A. Hasil Penelitian}

1. Penggunaan Virgin Coconut Oil 
Tabel 4.2. Distribusi Penggunaan Virgin Coconut Oil Pada Responden di Wilayah Kerja Puskesmas Depok II Sleman, Mei 2014.

\begin{tabular}{llcc}
\hline & & $\begin{array}{c}\text { Frekuensi } \\
(\mathbf{f})\end{array}$ & $\begin{array}{c}\text { Persentase } \\
(\%)\end{array}$ \\
\hline $\begin{array}{l}\text { Pengguna } \\
\text { anVCO }\end{array}$ & $\begin{array}{l}\text { Tidak teratur } \\
\text { menggunakan } v c O\end{array}$ & 3 & 21,4 \\
& $\begin{array}{l}\text { Teratur } \\
\text { menggunakan vco }\end{array}$ & 11 & 78,6 \\
\hline Total & & $\mathbf{1 4}$ & $\mathbf{1 0 0 , 0}$ \\
\hline
\end{tabular}

Sumber : Data primer, diolah.

Pengolesan VCO dilakukan selama 30 hari berturut-turut. Pengolesan $\geq 21$ hari sudah dapat digolongkan atau dianggap menggunakan $V C O$, dan untuk pengolesan $<21$ hari digolongkan tidak menggunakan VCO.

Berdasarkan tabel 4.2, diketahui bahwa $78,6 \%$ responden menggunakan $V C O$ dan $21,4 \%$ tidak menggunakan VCO. Menurut William (2007), kulit bayi yang sehat memerlukan tambahan minyak yang menyehatkan yaitu omega-3 dan minyak asam lemak jenuh.

Asam lemak jenuh terdapat pada minyak kelapa. Minyak kelapa memiliki komponen sebagai anti bakteri dan anti mikroba (Syah, 2006). Hal ini yang menunjukkan bahwa penggunaan VCO baik untuk melindungi kulit bayi dari bakteri penyebab diaper rash.

\section{Pencegahan Diaper rash}

Tabel 4.3. Distribusi kejadian Diaper rash Pada Responden di Wilayah Kerja Puskesmas Depok II Sleman, Mei 2014.

\begin{tabular}{llcc}
\hline & & $\begin{array}{c}\text { Frekuensi } \\
(\mathbf{f})\end{array}$ & $\begin{array}{c}\text { Persentase } \\
(\%)\end{array}$ \\
\hline $\begin{array}{l}\text { Diaper } \\
\text { rash }\end{array}$ & $\begin{array}{l}\text { Tidak } \\
\text { diaper rash } \\
\text { Diaper rash }\end{array}$ & 12 & 85,7 \\
& 2 & 14,3 \\
\hline Total & & $\mathbf{1 4}$ & $\mathbf{1 0 0 , 0}$
\end{tabular}

Sumber : Data primer, diolah.
Tanda dan gejala diaper rash setelah penggunaan VCO diukur dengan menggunakan lembar observasi. Berdasarkan hasil perhitungan apabila nilai hasil observasi $\geq 14$ maka digolongkan responden mengalami diaper rash, dan untuk nilai hasil observasi $<14$ digolongkan tidak mengalami diaper rash.

Berdasarkan tabel4.3, terlihat bahwa $85,7 \%$ responden tidak mengalami diaper rash. Hal ini lebih banyak jika di bandingkan dengan $14,3 \%$ responden yang mengalami diaper rash.

Pada penelitian ini $14,3 \%$ responden yang mengalami diaper rash tersebut berjenis kelamin lakilaki dan berusia antara 7-12 bulan. Menurut Serdaroglu (2010), bahwa diaper dermatitis banyak terjadi pada usia 9-12 bulan. Tidak ada perbedaan gender dan kelompok etnik tertentu.

Sedangkan untuk waktu penggunaan diaper keduanya menggunakan diaper $>12$ jam/hari. Diaper rash dipengaruhi oleh lama penggunaan diaper dimana semakin lama penggunaan diaper maka resiko terkena diaper rash juga semakin tinggi (Lim, 2013).

Selain itu Collins (2011), menyebutkan bahwa pemakaian popok yang lama menyebabkan kulit kesulitan bernafas. Padahal kulit membutuhkan waktu untuk bernafas yang salah satu fungsinya untuk penguapan atau membuang sisa-sisa metabolisme tubuh yang tidak digunakan.

3. Efektifitas Penggunaan Virgin Coconut Oil Terhadap Pencegahan Diaper Rash. 
Tabel 4.4. Distribusi Efektifitas Penggunaan Virgin Coconut Oil Terhadap Pencegahan Diaper rash Pada Responden di Wilayah Kerja Puskesmas Depok II Sleman, Mei 2014.

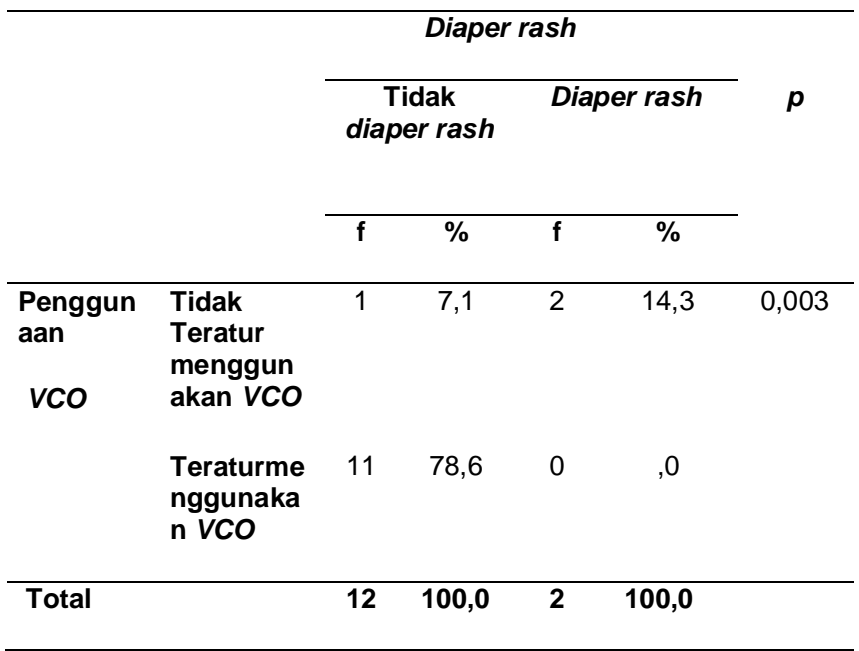

Sumber : Data primer, diolah.

Berdasarkan tabel 4.4, diketahui bahwa $21,4 \%$ responen yang tidak menggunakan VCO ditemukan $14,3 \%$ responden mengalami diaper rash. Sedangkan 78,6\% responden yang menggunakan VCO tidak mengalami diaper rash.

Pada $78,6 \%$ responden yang menggunakan VCO selama 30 hari, peneliti tidak menemukan tanda gejala diaper rash dan saat ibu diminta untuk melakukan pengolesan, para ibu mampu melakukan pengolesan sesuai dengan SOP dalam penelitian ini.

Menurut Sulistyowati (2009), penggunaan asam lemak jenuh pada VCO untuk pencegahan ruam popok dapat dioleskan 1-2 kali/hari selama 3-4 minggu. Pada penelitian ini pengolesan $1 \mathrm{kali} / \mathrm{hari}$ selama 30 hari sudah efektif untuk pencegahan diaper rash.

\section{KESIMPULAN DAN SARAN}

\section{A. Kesimpulan}

Dari hasil penelitian ini dapat disimpulkan bahwa :

1.

Penggunan VCO efektif terhadap pencegahan diaper rash pada bayi usia 1-12 bulan di wilayah kerja Puskesmas Depok II
Sleman yang dapat dilihat dari hasil uji statistik di peroleh nilai kemaknaan $p$ value $=0,003(p<$ $0,05)$ dengan interval kepercayaan $95 \%$.

2. Penggunaan VCO bermanfaat untuk kesehatan anak, khususnya untuk pencegahan terjadinya diaper rash. Hal ini terlihat dari data $78,6 \%$ responden tidak mengalami diaper rash setelah menggunakan VCO.

3. Frekuensi penggunaan VCO satu kali di pagi hari setelah mandi yang dilakukan selama $\geq 21$ hari lebih efektif terhadap pencegahan diaper rash dibandingkan dengan penggunaan $V C O<21$ hari.

\section{B. Saran}

1. Bagi petugas kesehatan khususnya perawat dan bidan, hendaknya dapat :

a. Memberikan informasi atau penyuluhan tentang efektifitas penggunaan $V C O$ dan cara pengolesan secara lengkap dan jelas pada ibu, karena hal ini dapat membantu meningkatkan kemandirian ibu dalam melakukan pencegahan diaper rash pada bayi.

b. Menggunakan hasil penelitian ini sebagai bukti dan acuan dalam meningkatkan keterampilan untuk melakukan tindakan preventif terjadinya diaper rash pada bayi.

2. Bagi para ibu yang memiliki bayi di Wilayah Kerja Puskesmas Depok II Sleman, agar dapat meningkatkan faktor-faktor yang dapat mengurangi resiko terjadinya diaper rash pada bayi secara khusus memperhatikan waktu penggunaan diaper yang baik, sehingga kenyamanan serta tumbuh kembang bayi dapat dicapai secara optimal.

3. Bagi peneliti selanjutnya, hendaknya dapat :

a. Menggunakan responden penelitian yang lebih besar agar hasil penelitian dapat 
mewakili populasi bayi yang menggunakan diaper.

b. Melakukan pretest dan posttest setelah intevensi agar dapat melihat perbedaan sebelum dan setelah intervensi dilakukan.

c. Memasukkan kelompok kontrol (tanpa perlakuan) yang dapat menjadi pembanding hasil penelitian selanjutnya.

d. Mengontrol tingkat kepatuhan responden lebih baik lagi serta melakukan observasi (posttest) secara langsung, sehingga data yang didapat akan lebih akurat.

\section{DAFTAR PUSTAKA}

Collins. 2011. Ensiklopedia Kesehatan Anak. Jakarta : Erlangga

Darsana. 2009. Pengaruh Perawatan Perianal Menggunakan Baby oil Terhadap Pencegahan Diaper Dermatitis Pada Neonatus di RSU. $D R$. Soetomo Surabaya. Skripsi.

Lim. 2013. Alergi Masa Kanak-Kanak : Semua yang Perlu Anda Ketahui Tentang Alergi Pada Anak-Anak. Jakarta : Indeks.

Manullang. 2010. Pengetahuan dan Tindakan Ibu Dalam Perawatan Perianal Terhadap Pencegahan Ruam Popok Pada Neunatus Di Klinik Bersalin. Skripsi. Universitas Sumatera Utara.

Notoatmodjo. 2012. Metodelogi Penelitian Kesehatan. Jakarta : Rineka Cipta.

Serdaroglu. 2010. Diaper Dermatitis (Napkin Dermatitis, Napkin Rash). Istanbul University Cerrahpaşa Medical Faculty Dermatology Department.

http://www.jtad.org/2010/4/jtad04401 r.pdf (04 Juni 2014).

Shazia, et.al. 2007. Diaper Dermatitis Frequenzy and Contributory Factors in Hospital Attending Children. www.ncbi.nlm.nih.gov/m/pubmed $/ 17$ 958792/(6 januari 2014).

Sopiyudin. 2013. Statistik Untuk Kedokteran dan Kesehatan. Jakarta : Salemba Medika.

Sulistyowati. 2009. Efek Asam Lemak Jenuh dan Asam Lemak Tak Jenuh "Trans" Terhadap Kesehatan. Puslitbang Biomedis dan Farmasi. Volume XIX. http://751-1855-1PB.pdf (07 Juni 2014).

Syah. 2006. Virgin Coconut Oil : Minyak Penakluk Aneka Penyakit. Jakarta : Agro Media Pustaka.

William. 2007. Everything You Need to Know About Your Baby From Birth to Age Two. Jakarta : Serambi Ilmu Semesta. 